BONAFIDE: Jurnal Teologi dan Pendidikan Kristen

www.jurnal.sttissiau.ac.id/Volume 1/Nomor 2/Desember 2020/hal.258-278

\title{
KONSEP PEMBENARAN MENURUT ROMA 5:1-11 DAN IMPLIKASINYA BAGI GEREJA MASA KINI
}

\author{
Finsen Deviston Bungan
}

Sekolah Tinggi Teologi Soteria Purwokerto

finsendevistonbungan@gmail.com

\begin{abstract}
In some churches, some see justification as an act of God so that Christians can enter heaven. According to biblical truth, this contradicts the concept of justification, as stated in Romans 5: 1-11. This paper intends to explore this part of the biblical text to obtain a correct concept of justification. The method used is text analysis syntactically and semantically, namely focusing on the text itself, interaction with other texts, and the Church Fathers' writings. The result of this research is that being justified means getting peace with God, not being enemies of God by living in sins. Being justified also means the church has access to God's Grace and is freed from God's wrath or God's judgment, and is saved by His life or saved by Jesus Christ.
\end{abstract}

Keywords: church, the result of justification, justification, Romans 5: 1-11

\begin{abstract}
Abstrak. Di kalangan gereja ada yang melihat pembenaran sebagai tindakan Allah supaya orang Kristen bisa masuk surga. Hal ini bertentangan dengan konsep pembenaran sesuai dengan kebenaran Alkitab sebagaimana tercantum dalam Roma 5:1-11. Tulisan ini bermaksud mengeksplorasi bagian teks Alkitab ini agar diperoleh konsep yang benar mengenai pembenaran. Metode yang digunakan adalah analisis teks secara sintaksis dan semantis yaitu fokus pada teks itu sendiri, interaksi dengan teks-teks lain dan tulisan para Bapa Gereja. Hasil penelitian didapatkan adalah bahwa dibenarkan berarti memperoleh damai dengan Allah, tidak menjadi seteru Allah dengan hidup dalam dosa-dosa. Dibenarkan juga berarti gereja memperoleh akses kepada Anugerah Allah dan dibebaskan dari murka Allah atau penghakiman Allah, serta diselamatkan oleh hidup-Nya atau diselamatkan oleh Yesus Kristus.
\end{abstract}

Kata Kunci: gereja, hasil pembenaran, pembenaran, Roma 5:1-11

\section{PENDAHULUAN}

Pembenaran adalah doktrin yang sangat penting bagi kehidupan orang percaya. Martin Luther berkata, "Ketika doktrin pembenaran runtuh, semua doktrin yang lain juga runtuh" (Boice 2015, 473). Doktrin pembenaran diumpamakan sebagai pemimpin atas segala macam doktrin. Pembenaran dalam Kamus Besa Bahasa Indonesia berarti proses, cara, perbuatan membenarkan. Jadi 
BONAFIDE: Jurnal Teologi dan Pendidikan Kristen

www.jurnal.sttissiau.ac.id/Volume 1/Nomor 2/Desember 2020/hal.258-278

pembenaran bukan hanya sebuah kata, teori atau ide, tapi sebuah cara, proses dan perbuatan. Jika pembenaran adalah sebuah tindakan maka kita perlu melihat hasilhasil apa saja yang didapatkan dari tindakan pembenaran. Namun hasil ini belum banyak di ketahui oleh orang percaya padahal hasil ini secara baik dituliskan oleh Paulus dalam surat Roma 5:1-11.

Pembenaran menjadi jaminan orang Kristen untuk masuk dalam kerajaan surga, tetapi pemikiran bahwa manusia dibenarkan Allah hanya untuk masuk surga adalah pemikiran yang jelas sempit dan materialistik. Masuk surga tentu adalah harapan yang wajar, tetapi karya penebusan Kristus dan hasil dari pembenaran yang dilakukan Yesus Kristus bukan hanya membawa orang masuk ke surga. Seperti yang dikatakan Sutjipto Subeno dalam khotbahnya,

Misi Kristus datang ke dunia bukan hanya memindahkan orang dari neraka ke surga. Ingat, surga tidak sama dengan dunia jangan pernah berpikir bahwa surga sebagai suatu tempat di mana di dalamnya segala sesuatunya terbuat dari emas. Itu pikiran manusia yang materialistis.(Subeno 2018, 435)

Hasil dari pembenaran dimengerti secara sempit, padahal hasil pembenaran begitu luas dan menyangkut keseluruhan hidup orang percaya, baik berlaku pada masa ia masih hidup ataupun sudah mati. Kurangnya pemahaman akan hasil pembenaran membuat orang percaya tidak mengerti akan tujuan dan pencapaian kenapa ia dibenarkan. Tidak tahu tujuan dan pencapaian membuat orang percaya bertindak, berlaku, tanpa sasaran, dan sembarangan. Oleh karena itu sangat penting bagi orang percaya untuk tahu hasil-hasil dari pembenaran. Ada dua alasan kenapa orang percaya harus tahu dan mengalami hasil pembenaran yang pertama supaya orang percaya mengetahui cara atau proses pembenaran, yang kedua, orang percaya dapat menikmati hasil tersebut. 
BONAFIDE: Jurnal Teologi dan Pendidikan Kristen

www.jurnal.sttissiau.ac.id/Volume 1/Nomor 2/Desember 2020/hal.258-278

Melalui tulisan ini penulis mencoba memberikan sebuah konsep atau cara pandang hidup sebagai orang yang sudah dibenarkan Allah dan menikmati pembenaran tersebut. Cara pandang ini disebut oleh Philip Graham Ryken sebagai "worldview". Menurutnya worldview idealnya adalah suatu kerangka kepercayaan dan keyakinan yang menolong kita melihat gambaran besar dari sudut pandang yang benar dan padu tentang makna eksistensi manusia.(Ryken 2016) Namun bagaimana jika worldview yang dianut keliru? Bagaimana jika orang percaya melihat diri dan hidup kekristenannya dengan sebuah worldview yang salah? Disadari atau tidak, sudut pandang yang mendasar tentang dunia dan kehidupan telah membentuk cara hidup orang percaya. Siapakah orang percaya dan bagaimana seharusnya mereka memandang nilai dirinya sebagai pribadi yang telah dibenarkan oleh Kristus? ini menjadi pertanyaan yang sangat penting yang perlu digumuli oleh gereja pada masa kini.

\section{METODE PENELITIAN}

Metode yang digunakan adalah pendekatan analisis teks secara sintaksis dan semantis yaitu fokus pada teks itu sendiri, interaksi dengan teks-teks lain dan tulisan para Bapa Gereja. Analisis teks adalah sebuah upaya untuk memahami sebuah teks Alkitab berdasarkan apa yang teks asli Alkitab itu sendiri nyatakan, berbeda dengan istilah eisegesis. Analisis teks berarti mengeluarkan atau mendapatkan makna asli dari Alkitab (O’Collins dan Farrugia 1998), sedangkan eisegesis itu memperoleh pengertian dari luar, kadang juga berdasarkan penalaran seseorang atau pengalaman dan asumsinya dalam memahami teks tersebut (Hipster 2017). 
BONAFIDE: Jurnal Teologi dan Pendidikan Kristen

www.jurnal.sttissiau.ac.id/Volume 1/Nomor 2/Desember 2020/hal.258-278

Berikut beberapa unsur analisis teks secara sintaksis dan semantis yang penulis pakai dalam penulisan ini. Yang pertama adalah historia; meneliti data teks Kitab Suci, di antaranya ada syntactic form (teks asli dalam bahasa Yunani) dan terjemahan literal untuk mendapatkan poin-poin syntactic, selanjutnya syntactic points yang telah didapatkan akan dianalisis ke dalam semantic content. Semantic content ini telah masuk ke dalam langkah theoria atau menemukan spritual meaning (pemahaman kerohanian). Kemudian semantic points berisi uraian dari poin-poin yang telah didapatkan dalam semantic content, dengan menginteraksikan poin-poin tersebut dengan teks-teks lain dalam Alkitab dan tulisan bapa-bapa gereja. Selain itu, poin-poin tersebut juga berisi eklesial yang berarti bahwa ajaran yang di dapatkan berpusat pada tradisi atau paradosis gereja yang dimulai dari para rasul dan bapa-bapa gereja secara lisan dan tulisan. Kemudian kita akan mendapatkan outline konsep yang berisi ringkasan dan rumusan konsep teologis yang dapat dibuat relevansinya (personal) yang berisi hal-hal yang dapat dikerjakan atau dipakai bagi kehidupan gereja pada masa kini.

\section{HASIL PENELITIAN}

Historia: Data Teks

Teks dan Syntactic Form (Teks asli Yunani yang dijabarkan dalam bentuk subjek dan predikat)

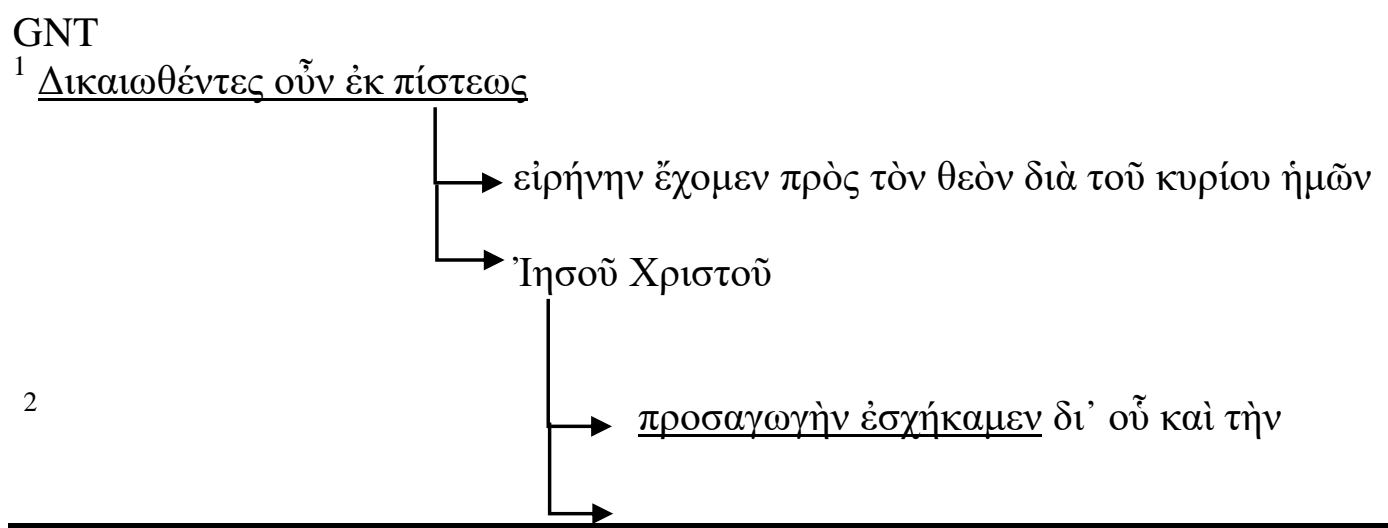




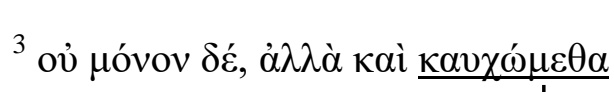
$\dot{\varepsilon} v \tilde{\tilde{n}} \dot{\varepsilon} \sigma \tau \dot{\kappa} \kappa \alpha \mu \varepsilon \nu$

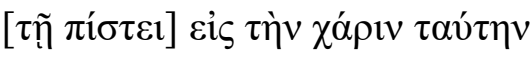

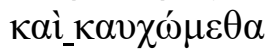

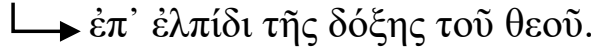

$\dot{\varepsilon} v \tau \alpha i \tilde{\varsigma} \theta \lambda i ́ \psi \varepsilon \sigma \mathrm{t} v$ $\varepsilon i \delta o ́ \tau \varepsilon \varsigma$ ő $\tau$

4

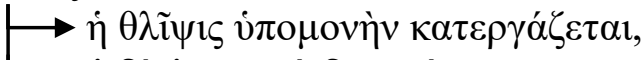

$\delta \dot{\varepsilon}$

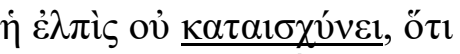

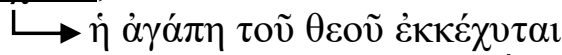

${ }^{6}$ yò

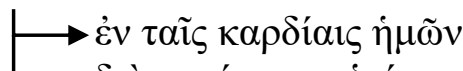

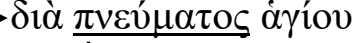

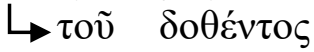
$\dot{\eta} \mu \mathrm{i} v$.

X

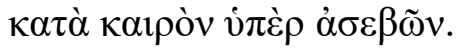

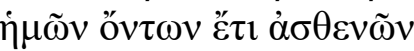

${ }^{7} \gamma \grave{\alpha} \rho \delta \dot{\varepsilon}$

$\tau i \varsigma \alpha \dot{\alpha} \pi \mathrm{o} \theta \alpha v \varepsilon i \tau \alpha \iota$

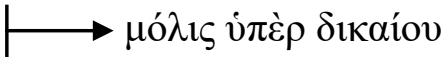

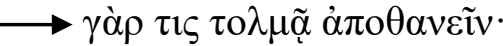

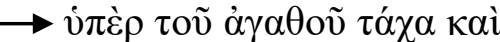

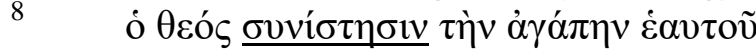

$\longrightarrow \operatorname{sic} \dot{\eta} \mu \tilde{\alpha} \varsigma$,

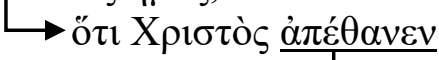

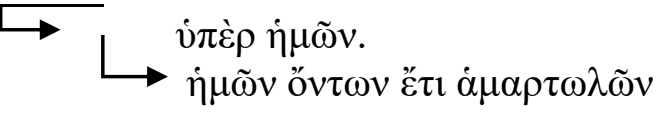

${ }^{9}$ oũv $\underline{\sigma \omega \theta \eta \sigma o ́ \mu \varepsilon \theta \alpha}$

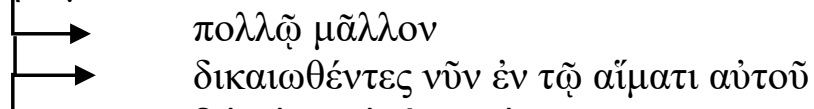

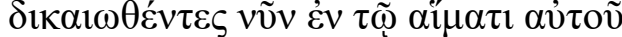

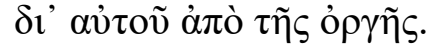

${ }^{10} \gamma \grave{\alpha} \rho \underline{\sigma \omega \theta \eta \sigma o ́} \mu \varepsilon \theta \alpha$

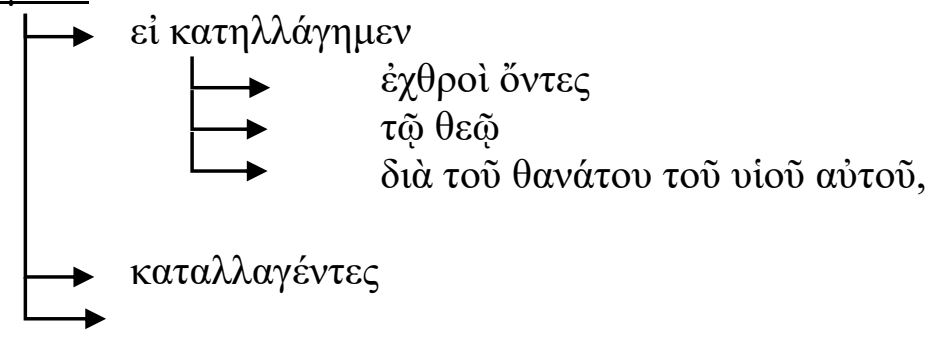


BONAFIDE: Jurnal Teologi dan Pendidikan Kristen

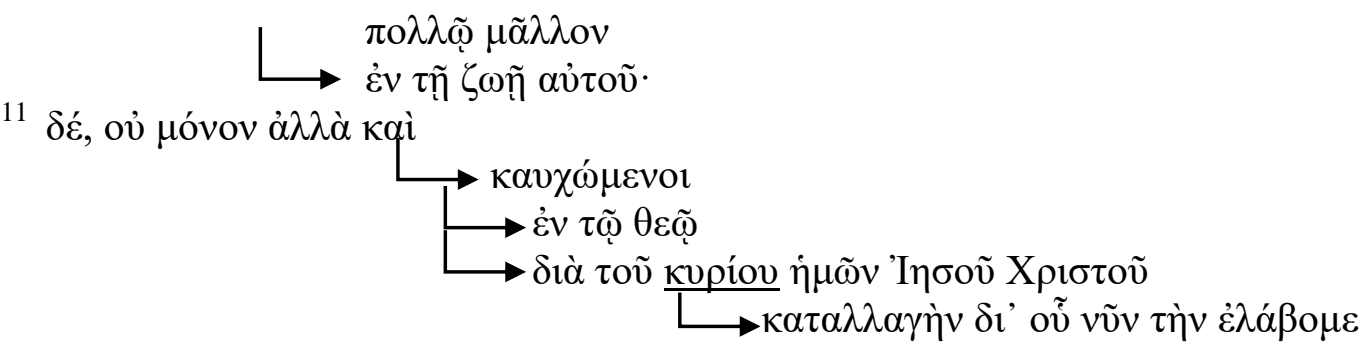

\section{Terjemahan Literal ${ }^{1}$}

${ }^{1}$ Sebab itu kita yang dibenarkan oleh iman memperoleh damai dengan Allah terus menerus karena Tuhan kita Yesus Kristus. ${ }^{2}$ Oleh Dia (Yesus Kristus) kita juga memperoleh akses atau jalan masuk oleh iman untuk masuk dalam anugerah. Dan di dalam anugerah ini kita berdiri dan kita bermegah dalam pengharapan akan menerima kemuliaan Allah. ${ }^{3}$ dan bukan hanya itu saja kita malah bermegah dalam kesengsaraan karena kita tahu, bahwa kesengsaraan itu menimbulkan ketekunan, ${ }^{4}$ dan ketekunan menimbulkan tahan uji dan tahan uji menimbulkan pengharapan. ${ }^{5}$ dan pengharapan itu tidak mempermalukan atau mengecewakan kita karena kasih Allah telah dicurahkan di dalam hati kita oleh Roh Kudus yang telah diberikan kepada kita. ${ }^{6}$ Karena Kristus telah mati menurut waktu-Nya bagi kita orang-orang durhaka saat kita masih lemah ${ }^{7}$ sebab tidak mudah seseorang mau mati untuk orang benar tetapi mungkin untuk orang yang baik ada orang yang mau mati ${ }^{8}$ Akan tetapi Allah menunjukkan kasih-Nya kepada kita, oleh karena Kristus telah mati untuk kita, ketika kita masih berdosa. ${ }^{9}$ lebihlebih kita pasti akan diselamatkan dari murka Allah, karena kita sekarang telah dibenarkan oleh darah-Nya ${ }^{10}$ Kita akan diselamatkan oleh hidup-Nya karena

1 Terjemahan ini berbeda dengan terjemahan Lembaga Alkitab Indonesia (LAI). Terjemahan literal adalah terjemahan yang didapatkan melalui teks asli Yunani yang telah diuraikan dalam bentuk subjek predikat seperti di atas. 
BONAFIDE: Jurnal Teologi dan Pendidikan Kristen

www.jurnal.sttissiau.ac.id/Volume 1/Nomor 2/Desember 2020/hal.258-278

ketika kita masih bermusuhan dengan Allah, kita direkonsiliasi oleh kematian Anak-Nya ${ }^{11}$ Dan bukan hanya itu saja! Kita malah bermegah dalam Allah oleh Yesus Kristus, Tuhan kita, sebab oleh Dia kita telah menerima pendamaian itu.

\section{Syntactic Point}

Ada empat hal yang kita terima ketika kita dibenarkan oleh Allah. Sebelumnya, di pasal 4 Paulus menjelaskan tentang pembenaran karena iman. Di pasal 5:1-11 Paulus memulai dengan kata oun "karena itu" untuk menyatakan hasil-hasil pembenaran karena iman tersebut. Berikut keempat hasil pembenaran karena iman. Pertama, kita menerima/memiliki (echomen) damai sejahtera eirenen dari Allah melalui Tuhan Yesus Kristus (1). Mengapa? Kata echomen (memiliki/menerima) dijelaskan oleh partisip dikaiwthentes (dibenarkan) karena (cause) atau oleh (means) iman. Jadi karena dibenarkan oleh iman kita memiliki hidup damai dengan Allah secara terus menerus. Kedua, kita sudah menerima / memiliki (Eschekamen) freedom atau jalan untuk memasuki anugerah (ay. 2). Apa yang terjadi ketika kita masuk ke dalam anugerah ini? Di dalam anugerah ini kita sudah berdiri teguh dan terus bermegah pada pengharapan kemuliaan Allah (ay. 2).

Selain itu kita juga bermegah kauchometha dalam penderitaan (ay. 3). Mengapa bermegah di dalam penderitaan? Pertama, kita sudah tahu eivdo,tej bahwa penderitaan menimbulkan ketabahan (ay. 3); ketabahan menimbulkan tahan uji (ay. 4), tahan uji menimbulkan pengharapan (ay. 4) dan pengharapan tidak mengecewakan karena kasih Allah telah dicurahkan dalam hati kita (ay. 5). Kedua, Christos Ontwn. Kristus menggantikan kita ketika kita masih berdosa atau 
BONAFIDE: Jurnal Teologi dan Pendidikan Kristen

www.jurnal.sttissiau.ac.id/Volume 1/Nomor 2/Desember 2020/hal.258-278

masih sakit (ay. 6). Ketiga, Allah menunjukkan kasih-Nya melalui kematian Yesus Kristus ketika kita masih berdosa (ay. 7-8). Keempat, kita akan diselamatkan (swthesometha) dari murka Allah karena sekarang kita dibenarkan oleh darah-Nya (ay. 9). Kelima, kita akan diselamatkan (swthesometha) oleh hidup-Nya karena ketika kita masih bermusuhan dengan Allah, kita direkonsiliasi oleh kematian Anak-Nya dan kita malah bermegah dalam Allah karena Yesus Kristus (ay. 10-11).

\section{Semantic Content}

Kita menerima atau memiliki (Echomen) damai sejahtera Eirenen dari Allah melalui Tuhan Yesus Kristus

Kita menerima atau memiliki (echomen) damai sejahtera eirenen dari Allah melalui Tuhan Yesus Kristus (1). Mengapa? Kata echomen (memiliki atau menerima) dijelaskan oleh partisip dikaiwthentes (dibenarkan) karena (cause) atau oleh (means) iman. Jadi karena dibenarkan oleh iman kita memiliki hidup damai dengan Allah secara terus menerus. Apa arti memiliki damai dengan Allah ? KBBI mengartikan kata damai adalah suatu keadaan tidak ada perang; tidak ada kerusuhan; aman; keadaan tidak bermusuhan; rukun (KBBI Daring 2016), sehingga memiliki damai dengan Allah berarti suatu keadaan tidak bermusuhan dengan Allah, bukan lagi menjadi seteru Allah, bapa gereja Chrysostom juga mengatakan, "Dia berkata, marilah kita memiliki damai, ”berarti, janganlah kita berbuat dosa lagi, atau kembali ke manusia lama kita. Karena ini berarti berperang dengan Tuhan" (Augustine, Chrysostom, dan Schaff 1956, 396). Tidak lagi kembali pada keadaan hidup yang dulu pada saat kita masih berdosa, karena pada 
BONAFIDE: Jurnal Teologi dan Pendidikan Kristen

www.jurnal.sttissiau.ac.id/Volume 1/Nomor 2/Desember 2020/hal.258-278

saat orang percaya hidup dalam dosa itu berarti ia menjadikan dirinya musuh

Allah. Ambrosiaster juga mengatakan:

Iman memberi kita damai sejahtera dengan Tuhan, bukan hukum. Karena itu mendamaikan kita dengan Tuhan dengan menanggung dosa-dosa yang telah menjadikan kita musuh Tuhan. Dan karena Tuhan Yesus adalah pelayan anugerah ini, melalui Dia kita memiliki damai sejahtera dengan Tuhan. Iman lebih besar dari pada hukum karena hukum adalah pekerjaan kita, sedangkan iman adalah milik Tuhan. Lebih jauh, hukum berkaitan dengan kehidupan kita saat ini, sedangkan iman berkaitan dengan kehidupan kekal. Tetapi siapa yang tidak berpikir seperti ini tentang Kristus, sebagaimana mestinya, tidak akan dapat memperoleh pahala iman, karena dia tidak memegang kebenaran iman." (Ambrosiaster 400Ma)

Pada pasal satu telah dijelaskan kehidupan yang dipenuhi dosa, hidup dalam kebohongan (sehingga pikiran-pikiran mereka menjadi gelap) kehidupan yang bobrok, iri hati, pembunuhan, perselisihan, penipuan, fitnah, gosip, umpatan, kebencian dan segala macam perbuatan jahat lainnya yang pada saat itu berkembang begitu pesat di Roma (Rm. 1:18-32). Jadi, memperoleh damai dengan Allah berarti orang percaya tidak lagi hidup dalam dosa-dosa.

Kita sudah menerima / memiliki (Eschekamen) freedom atau jalan untuk memasuki anugerah

Dibenarkan yang kedua berati kita menerima jalan masuk untuk memasuki Anugerah. Kata Yunani $\pi \rho \sigma \sigma \alpha \gamma \omega \gamma \grave{\eta} v$ diparsing noun accusative feminine singular dari kata $\pi \rho o \sigma \alpha \gamma \omega \gamma \eta^{\prime}$ yang diterjemahkan access (RSV, NKJ, NIV) atau jalan

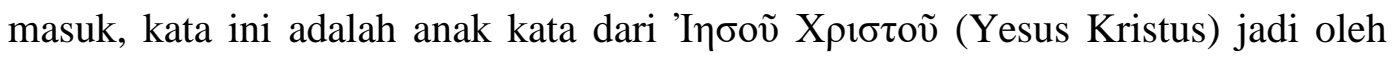
karena Yesus Kristus kita memperoleh jalan masuk kepada anugerah itu. Yesus berkata, "Akulah pintu; barangsiapa masuk melalui Aku, ia akan selamat dan ia akan masuk dan keluar dan menemukan padang rumput. (Yoh 10:9) kemudian Yesus mempertegas dengan berkata, "Kata Yesus kepadanya: "Akulah jalan dan 
BONAFIDE: Jurnal Teologi dan Pendidikan Kristen

www.jurnal.sttissiau.ac.id/Volume 1/Nomor 2/Desember 2020/hal.258-278

kebenaran dan hidup. Tidak ada seorangpun yang datang kepada Bapa, kalau tidak melalui Aku. (Yoh 14:6). Jadi oleh karena Yesus Kristus kita bisa datang kepada Bapa Ambrosiaster juga berkata,

Jelas bahwa di dalam Kristus kita memiliki akses ke kasih karunia Tuhan. Karena dia adalah perantara antara Tuhan dan manusia, yang membangun kita dengan ajaran-Nya dan memberi kita harapan untuk menerima anugerah rahmat-Nya jika kita berdiri dalam imannya. Oleh karena itu, jika kita berdiri (karena kita dulu rata dengan lantai) kita berdiri sebagai orang percaya, memuliakan pengharapan akan kemuliaan yang telah Dia janjikan kepada kita. (Ambrosiaster 400Mc)

Kondisi manusia yang telah berdosa dan tidak kudus kini dapat datang kepada Allah Bapa melalui Yesus Kristus, dalam 1 Petrus 3:18 dikatakan, "Sebab juga Kristus telah mati sekali untuk segala dosa kita, Ia yang benar untuk orangorang yang tidak benar, supaya Ia membawa kita kepada Allah; Ia, yang telah dibunuh dalam keadaan-Nya sebagai manusia, tetapi yang telah dibangkitkan menurut Roh," di dalam Yesus Kristus kita bukan hanya memperoleh pengampunan dosa tetapi kita mempunya jalan untuk hidup berkelimpahan. Seperti yang dikatakan Chrysostom dkk, "Karena bukan hanya agar kita memiliki pengampunan dosa, dan didamaikan dengan Allah; tetapi kita mungkin juga menerima manfaat yang tak terhitung jumlahnya. Dia bahkan tidak berhenti disitu, tetapi menjanjikan yang lain, yaitu, berkat yang tak terucapkan yang melewati pemahaman dan bahasa." (Augustine, Chrysostom, dan Schaff 1956, 397).

\section{Dibenarkan berarti Kita akan diselamatkan (Swthesometha) dari murka Allah}

Kata diselamatkan dalam bahasa Yunani $\sigma \omega \theta \eta \sigma o ́ \mu \varepsilon \theta \alpha$ (swthesometha) di parsing verb indicative future passive 1st person plural dari kata $\sigma \omega ́ \zeta \omega$. Ini berarti bahwa ketika seseorang telah dibenarkan dia juga pasti akan diselamatkan 
BONAFIDE: Jurnal Teologi dan Pendidikan Kristen

www.jurnal.sttissiau.ac.id/Volume 1/Nomor 2/Desember 2020/hal.258-278

berbentuk future, ini berbicara tentang keselamatan yang akan didapatkan oleh orang percaya pada saat dibenarkan, diselamatkan dari kematian yang kekal dan penghakiman (Yoh 5:24). Kata ini juga berbentuk passive karena bukan dilakukan oleh orang pertama (kita), tetapi dilakukan oleh Allah sendiri, Allah yang akan menyelamatkan, jadi tindakan menyelamatkan itu adalah inisiatif Allah bukan manusia.

Selanjutnya kata murka Allah (ỏ $\gamma \gamma \tilde{\eta} \varsigma)$ kata ini juga dipakai dalam Roma 2:5 yang ditunjukkan kepada orang-orang yang tidak mau bertobat atau orangorang yang masih hidup dalam dosa secara terus menerus, maka murka dan keadilan Allah akan dinyatakan kepada mereka. Alkitab mencatat bahwa ada suatu hari dimana murka Allah itu akan dinyatakan (Ams 11:4; Ayb 21:30). Aquinas juga berkata:

Jika Tuhan membiarkan Putranya dibunuh demi orang berdosa, apa yang akan dia lakukan bagi mereka yang telah dibenarkan kecuali menyelamatkan mereka dari murka, yaitu, menjaga mereka tidak terluka dari tipu daya Iblis, sehingga mereka selamat pada hari penghakiman. Karena kebaikan Tuhan tidak ingin ada yang binasa, dia telah menunjukkan belas kasihan kepada mereka yang pantas mati untuk meningkatkan kehormatan dan kemuliaan mereka yang memahami kasih karunia Tuhan.”(Raith II 2014, 88)

Ketika manusia itu dibenarkan maka ia memperoleh damai dengan Allah itu berarti ia tidak lagi hidup dalam dosa-dosanya, maka ia akan terbebas dan diselamatkan dari murka Allah dan memperoleh hidup yang kekal, tetapi kata diselamatkan $(\sigma \omega \theta \eta \sigma o ́ \mu \varepsilon \theta \alpha)$ tidak berdiri sendiri, itu dijelaskan oleh kata $\dot{\varepsilon} v \tau \tilde{\varphi}$

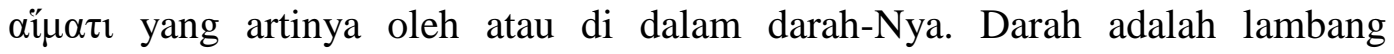
kehidupan, jadi kehidupan Yesus Kristus diberikan kepada manusia, Kristus harus mati untuk menyelamatkan manusia. Darah menyiratkan karya penebusan Kristus. 
BONAFIDE: Jurnal Teologi dan Pendidikan Kristen

www.jurnal.sttissiau.ac.id/Volume 1/Nomor 2/Desember 2020/hal.258-278

Kita akan diselamatkan (Swthesometha) oleh hidup-Nya

Selanjutnya hasil dari pembenaran yang keempat adalah kita akan diselamatkan (swthesometha) oleh hidup-Nya karena ketika kita masih bermusuhan dengan Allah. Kita direkonsiliasi oleh kematian Anak-Nya dan kita malah bermegah dalam Allah karena Yesus Kristus (10-11). Kristus menyelamatkan orang percaya oleh dirinya sendiri, dalam 2 Korintus 5:21 dikatakan, "Dan semuanya ini dari Allah, yang dengan perantaraan Kristus telah mendamaikan kita dengan diri-Nya dan yang telah mempercayakan pelayanan pendamaian itu kepada kami. Dipertegas juga oleh Paulus dalam Ibrani 7:25, ia katakan "Karena itu Ia sanggup juga menyelamatkan dengan sempurna semua orang yang oleh Dia datang kepada Allah. Sebab Ia hidup senantiasa untuk menjadi pengantara mereka.” Hendi juga menulis:

Penyaliban, penguburan dan kebangkitan Kristus adalah cara penebusan dilakukan. Penebusan artinya manusia dilepaskan dengan suatu bayaran dari kekuatan gelap yang mengungkungnya. Kekuatan gelap yang jahat itu adalah: Iblis, dosa dan maut. Bayaran yang diberikan untuk melepaskan manusia dari kungkungan Iblis, dosa dan maut itu adalah Derita, Penyaliban, Kematian dan Penguburan Kristus (Hendi 2019, 76)

Upah dosa ialah maut (Rm. 6:23) Adam sebagai manusia pertama melanggar perintah Allah dengan memakan buah pengetahuan yang baik dan yang jahat yang dilarang Allah dalam taman Eden, ini menyebabkan ia berdosa dan kita sebagai manusia keturunannya mewarisi dosa asal dari Adam. Oleh karena ketidaktaatan Adam manusia menjadi berdosa dan harga yang harus dibayar untuk menebus dosa-dosa manusia adalah melalui ketaatan Yesus Kristus di atas kayu salib (Rm. 5:19). 
BONAFIDE: Jurnal Teologi dan Pendidikan Kristen

www.jurnal.sttissiau.ac.id/Volume 1/Nomor 2/Desember 2020/hal.258-278

\section{PEMBAHASAN}

\section{Outline Concept dan Konsep Teologis}

Pembenaran, meliputi: Hidup damai dengan Allah, Kita memperoleh jalan atau akses untuk memasuki anugerah, Diselamatkan dari murka Allah atau penghakiman Allah, Kita diselamatkan oleh hidup-Nya

\section{Hidup Damai Dengan Allah}

Damai dengan Allah yang ditekankan dalam Roma 5: 1 adalah suatu keadaan dimana seseorang tidak menjadi seteru Allah. Seperti dikatakan yang dikatakan Paulus, “orang-orang yang tidak menerima Injil dan salib Kristus adalah seteru Allah" (Rm. 11:28; Flp 3:18) juga orang-orang yang masih hidup dalam dosa-dosanya, mengikuti hawa nafsunya dan hidup dalam keduniawiaan adalah musuh Allah, sebab barangsiapa yang masih hidup dalam dosa dan menjadi sahabat dunia serta mengikuti segala hawa nafsunya yang jahat, ia menjadikan dirinya musuh Allah (Yak 4:1-4).

Sehingga hidup damai dengan Allah bukan hanya soal status, tetapi sebuah kondisi iman seseorang. Orang yang masih hidup dalam dosa tidak memiliki damai dengan Allah karena imannya tidak bertumbuh. Damai dengan Allah secara esensial adalah mengenal dan menjadi sahabat Kristus dan bertumbuh dalam iman dan pengharapan kepada-Nya.

Damai dengan Allah adalah sebuah proses pengudusan atau bertumbuh menjadi dewasa, memiliki gaya perilaku yang berbeda, dari kehidupan sebelumnya (Dwiraharjo 2018). Ini berarti ada tahapan-tahapan yang harus dilalui 
BONAFIDE: Jurnal Teologi dan Pendidikan Kristen

www.jurnal.sttissiau.ac.id/Volume 1/Nomor 2/Desember 2020/hal.258-278

oleh orang yang telah mengalami damai dengan Allah, dimulai dari meninggalkan dosa-dosanya hingga menyatu dengan Allah yang adalah yang damai itu sendiri.

Aquinas dan Calvin juga dalam penafsiran mereka tentang pembenaran dalam surat Roma merujuk pada sebuah kondisi orang-orang yang telah dibenarkan dan yang telah memperoleh damai dengan Allah, tidak berhenti di situ saja atau dalam kondisi memperoleh status damai saja, mereka menulis bahwa orang-orang yang telah dibenarkan ikut berpartisipasi (bersinergi) dengan Allah supaya mereka sebagai orang-orang yang telah dibenarkan mengalami transformasi atau perubahan hidup di dalam Roh Kudus” (Raith II 2014, 149). Jadi jelas bahwa pembenaran mengarahkan pada kehidupan yang kudus dan tidak hidup dalam dosa-dosa.

\section{Kita Memperoleh Jalan atau Akses Untuk Memasuki Anugerah}

Teks dalam Roma 5:2 menegaskan bahwa kita yang telah dibenarkan

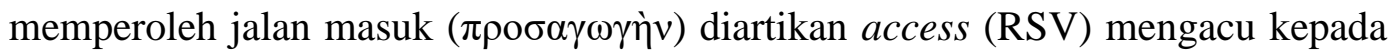
jalan menuju kepada Bapa melalui karya Roh Kudus (Ef 2:8) dan melalui iman

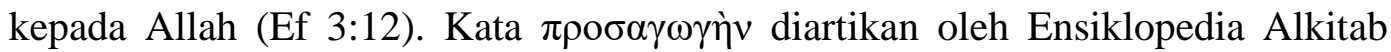
sebagai jalan masuk orang-orang berdosa ke dalam kehadiran-Nya. Mereka tidak mempunyai hak yang bebas untuk mengadakan pendekatan secara pribadi, dan memperoleh jalan masuk hanya melalui Kristus (Douglas 1997)

Terputusnya jalan menuju kepada Allah Bapa disebabkan oleh dosa manusia pertama, melalui karya keselamatan Yesus Kristus, Allah membawa manusia dari dosa kepada anugerah, dari keterasingan kepada rekonsialiasi, dari kematian kepada kehidupan kekal, kita yang dahulu jauh telah didekatkan kepada 
BONAFIDE: Jurnal Teologi dan Pendidikan Kristen

www.jurnal.sttissiau.ac.id/Volume 1/Nomor 2/Desember 2020/hal.258-278

Allah oleh Yesus Kristus. Jadi orang yang dibenarkan dapat datang kepada Allah karena Kristus telah menjadi perantara dan jalan untuk menuju kepada anugerah Allah.

\section{Diselamatkan Dari Murka Allah atau Penghakiman Allah}

Dalam Roma 5:9 menjelaskan bahwa kita yang dibenarkan diselamatkan dari murka Allah. Murka Allah dapat dimengerti sebagai terpisahnya Allah dengan manusia selamanya karena pilihan manusia itu sendiri untuk terus menjadi seteru Allah atau hidup dalam dosa-dosanya dan tidak mau bertobat dan datang kepada Allah. Dalam Roma 2:5 Paulus katakan, "Tetapi oleh kekerasan hatimu yang tidak mau bertobat, engkau menimbun murka atas dirimu sendiri pada hari waktu mana murka dan hukuman Allah yang adil akan dinyatakan.” Orang yang sudah dibenarkan, mengalami karya Kristus akan selalu hidup dalam pertobatan setiap saat sehingga ia terbebas dari hukuman Allah yang akan dinyatakan kelak. Tasker dalam penafsirannya pada surat Roma juga menjelaskan:

Memang, hanya oleh keselamatan yang rahmani, sehingga pendosa dapat tidak lagi menjadi sasaran murka dan menjadi penerima anugerah Allah. Kasih Allah terhadap pendosa yang dinyatakan dalam hidup dan kematian Yesus merupakan tema utama perjanjian baru dan kasih itu dinyatakan pada kita. Yesus Kristus harus mengalami kesengsaraan, penderitaan, hukuman dan kematian yang seharusnya ditanggung oleh orang yang berada di bawah murka Allah. Murka Allah tetap atas semua orang yang mencoba merintangi maksud Allah yang kekal dan tidak tunduk kepada Anak Allah, yang hanya melalui Dia saja pembenaran dapat dimungkinkan. (Tasker 1951, 105)

Pembenaran juga dilihat sebagai pilihan untuk merespon dengan iman karya penebusan Kristus, kemudian iman ini harus di refleksikan dalam perbuatan, sehingga iman ini tidak menjadi mati (Yak 2:14). Jadi dibenarkan 
BONAFIDE: Jurnal Teologi dan Pendidikan Kristen

www.jurnal.sttissiau.ac.id/Volume 1/Nomor 2/Desember 2020/hal.258-278

bukan menjadikan orang yang dibenarkan itu pasif, tetapi justru aktif dalam merespon anugerah Tuhan dan merefleksikan dalam kehidupan sehari-hari, Pembenaran juga mengingatkan orang Kristen untuk selalu hidup dalam pertobatan, tanpa pertobatan tidak mungkin dapat terbebas dari murka Allah.

\section{Kita Diselamatkan Oleh Hidup-Nya}

Kata oleh hidup-Nya yang dituliskan dalam Roma 5: 10 seperti yang telah diuraikan diatas menunjuk pada Kristus sendiri. Keseluruhan hidup dari Kristus adalah keselamatan bagi manusia. Jhon Chrysostom dalam tafsirannya pada Roma 5:10-11 juga mengatakan, "Suatu fakta yang menarik adalah bahwa kita yang adalah orang berdosa diselamatkan bukan oleh malaikat-malaikat, tetapi oleh Putra satu-satunya yang diperanakkan Allah (Yesus Kristus), Dialah yang menyelamatkan kita" (Ambrosiaster 400Mb).

Kelahiran Kristus kedalam dunia memberi harapan baru bagi manusia, manusia yang telah jatuh dalam dosa karena ketidaktaatan Adam, dibayar dengan ketaatan Kristus di kayu salib. Apa yang dikerjakan Kristus telah membawa manusia kembali kepada Allah Bapa. Orang Kristen harus bersukacita dalam Tuhan karena melalui Yesus Kristus sebagai pengantara yang memungkinkan mereka datang kepada Allah. Orang Kristen telah menerima setiap berkat melalui Kristus, bahwa melalui Dia mereka telah mengenal Tuhan. Pada saat gereja menghormati Allah, gereja juga menghormati Anak-Nya Yesus Kristus yang telah memberikan hidup-Nya. 
BONAFIDE: Jurnal Teologi dan Pendidikan Kristen

www.jurnal.sttissiau.ac.id/Volume 1/Nomor 2/Desember 2020/hal.258-278

Personal

Pada masa kini gereja mengalami tantangan sebagai orang yang sudah dibenarkan oleh Allah, secara khusus orang-orang Kristen sulit hidup damai dengan Allah atau sulit hidup tanpa dosa-dosa. Dalam gereja sendiri banyak pemimpin gereja tidak dapat di teladani oleh generasi muda, sehingga generasi muda saat ini banyak yang memutuskan untuk tidak ke gereja karena mendapati kemunafikan dalam gereja (Lori 2020). Tidak hidup dalam dosa-dosa adalah pergumulan setiap saat orang Kristen, sehingga panggilan gereja adalah hidup dalam kekudusan setiap saat.

Dibenarkan Allah membuat gereja memperoleh akses tanpa batas kepada Allah. Anugerah Allah terus tersedia bagi gereja, tetapi dalam realita hidup bergereja masih banyak orang yang tidak datang kepada Allah meminta Anugerah-Nya dalam doa, justru mereka pergi ketempat-tempat lain untuk mencari pertolongan seperti dukun dan sebagainya. Dibenarkan Allah seharusnya membuat gereja dengan penuh kesadaran terus meminta Anugerah dan bantuan Allah untuk menyelamatkannya dari situasi-situasi yang ada. (Wright 2008).

Pada masa kini gereja kesulitan untuk hidup kudus dan tanpa dosa, mengingat seluruh akses yang menggiurkan untuk melakukan dosa terbuka melalui berbagai media yang tersedia di sekitar, bahkan melalui internet. Hampir tidak mungkin orang Kristen tidak berbuat dosa dalam satu hari, karena itu diperlukan pertobatan setiap saat. Pertobatan menjadi kunci penting bagi gereja, karena itu pada liturgi-liturgi ibadah Kristen perlu adanya pengakuan dosa dan 
BONAFIDE: Jurnal Teologi dan Pendidikan Kristen

www.jurnal.sttissiau.ac.id/Volume 1/Nomor 2/Desember 2020/hal.258-278

pertobatan. Pada saat seseorang dibenarkan itu berarti panggilan untuk hidup dalam pertobatan setiap saat.

Gereja juga perlu menyadari bahwa pembenaran bukan hanya membawa membawa orang Kristen masuk surga, tetapi gereja juga harus melihat pembenaran dengan pikiran yang terbuka sesuai dengan kebenaran Kitab Suci.

\section{KESIMPULAN}

Pembenaran adalah tindakan Yesus Kristus untuk menyelamatkan dunia, dengan peristiwa inkarnasi, Firman jadi manusia. Firman itu hidup di dalam diri Yesus Kristus. Ia di lahirkan, bertumbuh dewasa, mengajar, kemudian disalibkan, mati dan dibangkitkan. Seluruh kehidupan Yesus Kristus yang tercatat dalam Alkitab adalah Injil itu sendiri. Tetapi hasil dari pembenaran ini, sering diabaikan oleh orang percaya.

Berdasarkan hasil penelitian bahwa konsep pembenaran menurut Roma 5:1-11 adalah sebagai berikut.

Pertama, memperoleh damai dengan Allah. Damai dengan Allah dalam surat Roma ini tidak mengarah pada suatu perasaan batiniah, sekalipun orang yang berdamai dengan Allah secara batiniah mengalami perasaan damai tersebut, tetapi damai dengan Allah yang dimaksud disini adalah tidak menjadi seteru Allah atau musuh Allah. Hal ini mengarah pada suatu hubungan antara Allah dan manusia yang telah di benarkan. Orang yang telah dibenarkan menyatakan hidupnya di pihak Allah dan di terangi kasih Allah, sehingga ia tidak lagi hidup dalam dosa-dosa dan menjadi sahabat dunia (mengarah pada perbuatan-perbuatan yang jahat) orang yang telah dibenarkan memiliki pertumbuhan iman yang baik, 
BONAFIDE: Jurnal Teologi dan Pendidikan Kristen

www.jurnal.sttissiau.ac.id/Volume 1/Nomor 2/Desember 2020/hal.258-278

sehingga damai dengan Allah berarti pertumbuhan iman ke arah kedewasaan menjadi serupa dengan Kristus, inilah yang membuat orang yang telah dibenarkan tidak lagi hidup dalam dosa yang menjadikan ia seteru Allah, sekalipun dalam pergumulan hidupnya ia dapat berdosa lagi, tetapi selalu ada damai Allah yang tersedia, sehingga ia mampu menyadari dan kembali kepada Allah. Hal ini tidak terlepas dari pekerjaan Roh Kudus yang dicurahkan bagi orang yang telah dibenarkan, sehingga Roh Kudus inilah yang terus mengingatkan dan menginsafkan ia akan dosa-dosanya (Yoh 16:8).

Kedua, memperoleh jalan atau akses untuk memasuki anugerah. Oleh karena dosa kita kehilangan akses atau jalan kembali kepada Allah Bapa, ketika kita dibenarkan kita memperoleh kembali akses itu melalui Yesus Kristus kita memperoleh jalan untuk kembali kepada Bapa. Anugerah Allah itu kini tersedia bagi semua umat manusia. melalui karya keselamatan Yesus Kristus, Allah membawa manusia dari dosa kepada anugerah, dari keterasingan kepada rekonsialiasi, dari kematian kepada kehidupan kekal, kita yang dahulu jauh telah didekatkan kepada Allah oleh Yesus Kristus. Tetapi Anugerah Allah yang tidak terbatas itu, harus di responi oleh iman manusia, karena manusia sendiri di karuniakan kehendak bebas untuk memilih segala sesuatu untuk kehidupannya, sehingga walaupun Anugerah dan jalan itu terus tersedia, ia harus tetap merespon dengan kehendak bebasnya menerima Anugerah Allah itu untuk masuk dalam kehidupannya dan menyelamatkannya. Setiap manusia memerlukan Anugerah tersebut setiap detik kehidupannya. 
BONAFIDE: Jurnal Teologi dan Pendidikan Kristen

www.jurnal.sttissiau.ac.id/Volume 1/Nomor 2/Desember 2020/hal.258-278

Ketiga, diselamatkan dari murka Allah atau penghakiman Allah. Di sini orang yang telah dibenarkan Allah terbebas dari murka Allah yang menyala-nyala yang akan dinyatakan kelak (Rm. 2:5). Murka Allah itu ditunjukkan secara khusus kepada orang-orang yang berdosa, yang mengeraskan hatinya dan tidak mau bertobat. Pertobatan menjadi kunci penting supaya seseorang dapat terus hidup di dalam Kasih Allah. Pertobatan dan air mata akan membersihkan jiwa kita dari berbagai nafsu dan keinginan jahat dan membawa kita kembali kepada terang Kasih Allah, sehingga pertobatan itu sendiri harus dilakukan setiap saat, tanpa henti, bukan hanya pada saat dibaptis saja.

Keempat, diselamatkan oleh hidup-Nya. Kata oleh hidup-Nya berarti keselamatan itu diperoleh oleh orang yang telah dibenarkan melalui hidup Yesus Kristus. Keseluruhan kehidupan Kristus adalah keselamatan itu sendiri. Jadi tidak bisa dipisahkan. Injil bukan hanya peristiwa kematian Kristus, juga bukan hanya Natal, tetapi Injil atau berita keselamatan itu adalah keseluruhan kehidupan Yesus Kristus yang tercatat dalam Alkitab. Itulah yang menyelamatkan manusia.

Semua hal di atas adalah pengertian dibenarkan. Manusia yang telah dibenarkan, berarti memperoleh damai dengan Allah, memperoleh akses kepada Anugerah Allah, diselamatkan dari murka Allah dan diselamatkan oleh hidup Yesus Kristus sendiri. Pembenaran ini bersifat kekal yang berguna bagi kehidupan gereja pada saat ini maupun pada saat kedatangan Kristus yang kedua kali.

\section{DAFTAR PUSTAKA}

Ambrosiaster. 400Ma. "Romans 5:1 ." Catena Bible \& Commentaries. 400M. http://catenabible.com/rom/5/1. 
BONAFIDE: Jurnal Teologi dan Pendidikan Kristen

400Mb. "Romans 5:11 ." Catena Bible \& Commentaries. 400M. http://catenabible.com/com/584b75329ac03ecd4b8e4ecf.

- 400Mc. "Romans 5:2 ." Catena Bible \& Commentaries. 400M. http://catenabible.com/rom/5/2.

Augustine, John Chrysostom, dan Philip Schaff. 1956. A Select library of the Nicene and post-Nicene fathers of the Christian church. [1st series]. Michigan: W.R. Eerdmands Publishing.

Boice, James Montgomery. 2015. Dasar-Dasar Iman Kristen. Surabaya: Momentum.

Douglas, J.D., ed. 1997. Ensiklopedi Alkitab Masa Kini . Jakarta: Yayasan Komunikasi Bina Kasih.

Dwiraharjo, Susanto. 2018. "Persembahan yang Hidup Sebagai Buah dari Pembenaran Oleh Iman Menurut Roma 12:1-2." PRUDENTIA: Jurnal Teologi dan Pendidikan Kristiani 1 (1): 1-24.

Hendi, H. 2019. Inspirasi Kalbu 3. Yogyakarta: Leutikaprio.

Hipster. 2017. "Mempersiapkan Khotbah: Eksegesis VS Eisegesis." Cofee_Hipster's. 2017. http://hisptercoffee.blogspot.com/2017/03/ mempersiapkan-khotbah-eksegesis-vs.html.

KBBI Daring. 2016. "Damai.” kbbi.kemdikbud. 2016. https://kbbi.kemdikbud. go.id/entri/DAMAI.

Lori. 2020. "Anak Muda Rentan Tinggalkan Gereja? Lembaga Riset Barna \& Bilangan Riset Temukan Alasannya." Jawaban.com. 2020. https://www.jawaban.com/read/article/id/2020/02/11/58/200211092647/anak _muda_rentan_tinggalkan_gerejalembaga_riset_barna_bilangan_riset_temuk an_alasannya.

O’Collins, Gerald, dan Edward G. Farrugia. 1998. Kamus Teologi. Yogyakarta: Kanisius.

Raith II, Charles. 2014. Aquinas and Calvin on Romans: God's Justification and Our Participation. New York: Oxford University Press.

Ryken, Philip Graham. 2016. Christian Worldview: Mengembalikan Tradisi Intelektual Kristiani. Jakarta: Literatur Perkantas.

Subeno, Sutjipto. 2018. Ringkasan Khotbah Jilid 2. Surabaya: Gereja Reformed Injili Indonesia Surabaya-Andhika.

Tasker, R V G. 1951. The Biblical Doctrine of The Wrath of God. London: The Tyndale Press.

Wright, Christopher J. H. 2008. Keselamatan Milik Allah Kami. Surabaya: Literatur Perkantas. 